\title{
Meningkatkan Pengenalan Warna Melalui Finger Painting Pada Anak Usia 4-5 Tahun di PAUD Permata Bunda Muaro Jambi
}

\author{
Yesika Nadila \\ Pendidikan Guru Pendidikan Anak Usia Dini \\ Universitas Negeri Jambi \\ yesikanadila0803@gmail.com
}

\begin{abstract}
This research is due to the undevelopment of color recognition in children seen from the time of the learning process. The purpose of this research is to improve color recognition through finger painting at the age of children 4-5 years. This type of research used class action research, with the research stage covering the preparation of the plan, implementation of action, observing and reflecting on the final outcome of the activities that have been implemented. This research focuses on children aged 4-5 years PAUD Permata Bunda Muaro Jambi which the subject of this study is a group of 15 children, consisting of 10 men and 5 women. Research is conducted in 2 cycles. Each cycle is 4 times the meeting. Data on research results are analyzed using quantitative descriptive analysis. Data analysis techniques are obtained through the filling of the orservation sheet of observations that form field records and documentation. The results showed that there was an increase in color recognition through finger painting activities in PAUD Permata Bunda Muaro Jambi, namely: from the preview only 20.67\% of children know the color, The first Cycle 1st meeting 25.33\%, first Cycle second meeting 35.33\%, first Cycle in third meeting 46\% and first Cycle 4th meeting 47.33\%. In the second cycle the increase in color recognition of children already showed the first meeting $58 \%$, the second cycle of the second meeting $68 \%$, the second cycle of the $3 \mathrm{rd}$ meeting $80.67 \%$, the end of second cycle of the 4 th meeting $90 \%$ achieved the criteria of the value of the compensation is $90 \%$. The 4 th meeting reached $90 \%$.
\end{abstract}

Keywords : Color Recognition, Finger painting

\section{Abstrak}

Penelitian ini dilatar belakangi oleh belum berkembangnya pengenalan warna pada anak dilibat dari waktu proses pembelajaran berlangsung. Tujuan penelitian ini yakni untuk meningkatkan pengenalan warna melalui finger painting pada usia anak 4-5 tabun. Jenis penelitian digunakan Penelitian Tindakan Kelas (PTK), dengan tahap penelitian meliputi penyusunan rencana, pelaksanaan tindakan, mengobservasi dan melakukan refleksi terhadap hasil akhir atas kegiatan yang telah dilaksanakan. Penelitian ini berfokus pada anak usia 4-5 tahun PAUD Permata Bunda Muaro Jambi yang subyek, penelitian ini adalah kelompok. A yang berjumlah 15 anak, terdiri dari 10 laki-laki dan 5 perempuan. Penelitian dilakukan dalam 2 siklus. Masing-masing siklus terdapat 4 kali pertemuan. Data hasil penelitian dianalisis menggunakan analisis deskriptif kuantitatif. Teknik analisis data diperoleb melalui pengisian lembar orservasi dari pengamatan yang berupa catatan lapangan dan dokumentasi. Hasil penelitian menunjukkan bahwa adanya peningkatan pengenalan warna melalui kegiatan finger painting di PAUD Permata Bunda Muaro Jambi yaitu: dari pratindakan hanya 20,67\% anak mengenal warna, Siklus I pertemuan ke-1 25,33\%, siklus I pertemuan ke-2 35,33\%, siklus I pertemuan ke-3 46\% dan sik.lus 1 pertemuan ke-4 47,33\%. Pada Siklus II peningkatan pengenalan warna anak sudab menunjukkan pertemuan ke-1 58\%, siklus II pertemuan ke-2 68\%, siklus II pertemuan ke-3 80,67\%, akbir 
siklus II pertemuan ke-4 90\% mencapai kriteria nilai ketuntasan yaitu 90\%. Pertemuan ke-4 mencapai $90 \%$.

Kata Kunci: Pengenalan Warna, Finger painting

\section{A. PENDAHULUAN}

Pendidikan merupakan salah satu aspek kehidupan yang paling urgent. Setiap fase kehidupan dilalui dengan proses pembelajaran. Pembelajaran bisa diperoleh melalui pendidikan. Pendidikan tidak lagi hanya dimulai pada sekolah dasar taman kanak-kanak, namun sudah diawali lebih dini. Pendidikan Anak Usia Dini (PAUD) ditujukan untuk membantu pertumbuhan dan perkembangan anak secara optimal, agar memiliki kesiapan memasuki pendidikan lebih lanjut (Sofyan 2015). Pertumbuhan PAUD di Indonesia yang sangat pesat bukan hanya pada kuantitas, tetapi juga perubahan yang signifikan diberbagai segi (Suyadi dan Maulidya 2013). Hal ini terlihat semakin berkembangnya metode pendidikan yang diterapkan sehingga menambah ranah kreatifitas dalam meningkatkan mutu pendidikan pada anak usia dini.

Perkembangan anak pada usia dini tidak hanya tertumpu pada aspek tunggal perkembangan tetapi juga secara kolaboratif memacu pada seluruh aspek perkembangan anak. Anak pada usia dini adalah individu yang memiliki karakteristik yang unik dan memiliki kekhususan baik dari segi kognitif, sosial, emosi, nilai moral dan agama, bahasa, fisik, motorik, seni dan seluruh hal tersebut sedang mengalami proses perkembangan yang sangat pesat. Pada masa ini menjadi hal yang sangat fundamental bagi kehidupan mereka selanjutnya (Karuniawati 2017). Bagaimana anak dididik dan diasuh akan berdampak pada aspek kehidupan anak pada masa yang akan datang. Selain itu Berk dalam (Sujiono 2013) juga menambahkan bahwa pada masa ini proses perkembangan dalam berbagai aspek sedang mengalami masa yang cepat dalam rentang perkembangan hidup manusia. Maka dari itulah usia 0 sampai 6 tahun adalah usia emas (golden age). Golden age menjadi masa yang paling penting dan sangat berharga dalam perkembangan anak dalam perkebangan aspek. Dalam berbagai aspek perkembangan, aspek kognitif merupakan bagian vital untuk dikembangkan berkaitan kemampuan berpikir anak untuk dapat melakukan proses pembelajaran dan memiliki kemampuan dalam memecahkan masalah dan membantu anak untuk terus berkembang.

Pada kurikulum taman kanak-kanak dijelaskan bahwa kompetensi dasar yang harus dikuasai dalam bidang perkembangan kognitif yaitu anak mampu mengenal konsep sederhana dalam kehidupan sehari-hari. Adapun tingkat pencapaian perkembangan anak yang diharapkan untuk anak dapat mengenal konsep-konsep sains sederhana yang salah satu indikatornya adalah mampu mengenal warna. Pengenalan warna dapat merangsang indera penglihatan, otak dan emosi. Warna merupakan pantulan cahaya dari bendabenda sehingga warna merupakan unsur pertama yang terlihat oleh mata dari suatu benda. Menurut Nurdiana warna artinya corak atau motif dalam sebuah karya seni, selain itu Nurdiana juga menuliskan warna adalah salah satu unsur keindahan dan desain selain unsur visual seperti garis, bidang, bentuk, nilai dan ukuran (Yetri, 2014).

Berdasarkan hasil observasi yang dilakukan di PAUD Pertama Bunda pada tanggal 18 Maret 2019, bahwa dari 15 anak usia 4-5 masih terdapat anak yang masih belum optimal dalam mengenal warna dasar tersebut. Kegiatan pengenalan warna digunakan guru hanya pada kegiatan awal pembelajaran. Menurut salah satu guru kelas kelompok A dari wawancara singkat bahwa dari 15 anak kelompok A ada beberapa anak yang tampak aktif dalam pembelajaran, seperti pada saat mewarnai gambar dalam buku anak dapat menyebutkan warna yang digunakan untuk menggambar. Selain itu kegiatan pembelajaran lebih sering menggunakan kegiatan menempel dan menirukan huruf. 
Masih belum berkembangnya pengenalan warna pada anak dilihat dari waktu proses pembelajaran berlangsung seperti, pada saat kegiatan penjelasan materi pembelajaran guru melakukan tanya jawab tentang warna, namun hanya beberapa anak yang tampak benar menanggapi pertanyaan guru, yakni fikri, alif, dan afaf. Selama melakukan proses pembelajaran didalam kelas anak lebih banyak menggunakan buku tulis maupun buku gambar.

Mengenalkan konsep warna kepada anak sedari dini termasuk dalam kemampuan kognitif-logik. Rasyid dalam (Karuniawati 2017) menyatakan bahwa kemampuan kognitif-logika anak usia dini meliputi: mengklasifikasi, menyebut, membedakan, menghitung benda, warna, jarak, waktu, ukuran, bobot, dan bentuk. Seharusnya dalam pengenalan warna ada banyak cara yang dapat dilakukan guru, seperti mencoba menerapkan sistem yang baru atau media yang baru seperti kegiatan finger painting yang memiliki banyak manfaat diantaranya melatih motorik halus anak, mengembangkan indera peraba, melatih kreativitas anak, melatih imajinasi anak, memberikan sensasi pada jari sehingga dapat merasakan kontrol gerakan jari dan membentuk konsep warna dan mengembangkan bakat seni. Hal ini selaras dengan penelitian yang dilakukan oleh Anggraini, dkk bahwa ada perbedaan pengenalan warna antara anak yang belajar tanpa menggunakan permainan finger painting terhadap pengenalan warna pada anak kelompok usia 5-6 tahun di TK Bela Bangsa Mandiri bandar lampung (Anggraini, Jaya, dan Sofia 2018).

Pembelajaran pengenalan konsep warna terhadap anak harus menyesuaikan teknik yang digunakan dengan perkembangan anak. Salah satu teknik yang baik untuk pengenalan warna pada anak usia dini yaitu melalui kegiatan finger painting. Pengenalan warna dengan cara yang bervariasi dapat menarik perhatian anak untuk belajar tentang konsep pengenalan warna yaitu salah satunya dengan cara finger painting. Kegiatan tersebut dapat menstimulus anak untuk berfikir lebih baik karena dimana kegiatan finger painting ini anak melukis dengan menggunakan jari-jari. Anak dapat mengekspresikan diri. anak dapat mencampurkan warna primer sehingga terbentuk lah warna baru atau warna sekunder.

Saat melakukan finger painting anak terlibat secara aktif untuk mengekspresikan ideide dalam menghasilkan sebuah karya. Kegiatan finger painting sesuai dengan prinsip pembelajaran aktif dan inovatif. Guru harus mampu menstimulus keaktifan dan kreatifitas anak dan memberikan apresiasi terhadap hasil karya anak seperti yang dituliskan (Meldina 2019) bahwa guru juga harus mampu memberikan apresiasi positif terhadap segala keaktifan siswa selama proses pembelajaran berlangsung. Strategi pembelajaran ini menstimulasi anak untuk secara aktif membangun pengetahuan melalui berbagai kegiatan secara mandiri ataupun berkelompok. Kegiatan finger painting juga memberikan kesempatan pada anak untuk berimajinasi dalam mencipatakan gambar serta mengekspresikan ide warna yang akan dihasilkan. Melalui finger painting anak mampu berfikir dan bisa bereksplorasi terhadap warna-warna baru yang dihasilkannya.

Kurang maksimalnya pembelajaran yang bisa menggali kemampuan warna dan kurang terlibatnya anak dalam mengeksplorasi media atau sumber belajar yang bisa menstimulasi dan mengasah pengenalan warna pada anak merupakan faktor utama yang menjadi masalah mengapa anak memiliki kemampuan yang minim khususnya dalam pengenalan warna.

Tahap awal yang dilakukan oleh peneliti pra dilaksanakan penelitian adalah melakukan pengamatan (observasi) awal berupa kegiatan pratindakan (sebelum dilakukan tindakan) tanpa menggangggu proses pembelajaran anak. Hal ini dilakukan untuk mengetahui kondisi awal terhadap kemampuan pengenalan warna pada anak kelompok A di PAUD Permata Bunda Muaro Jambi dengan menggunakan lembar observasi. Berdasarkan lembar observasi yang peneliti lakukan selama ini bahwasannya 
pengenalan warna anak perlu ditingkatkan lagi karena ditemukan beberapa anak yang mempunyai pengenalan warna anak berada pada kategori kurang. Hal ini terlihat anak belum mampu menyebutkan warna ketika selesai menggambar dan disitu guru menanyakan ini warna apa dan anak masih binggung, adapun yang menjawab dan jawabannya salah seperti ketika menanyakan warna merah anak menyebut itu warna pink, selanjutnya warna biru anak menyebut itu warna hijau. Untuk itu peneliti mencoba untuk meningkatkan pengenalan warna anak usia dini khususnya di PAUD Permata Bunda Muaro Jambi melalui finger painting. Dengan menggunakan finger painting ini diharapkan pengenalan warna pada anak dapat meningkat sesuai dengan perkembangannya. Hasil peneliti bisa diukur melalui tingkat pencapaian perkembangan dengan indikator yang telah ditentukan.

\section{B. METODE PENELITIAN}

Jenis penelitian yang dilakukan yaitu Penelitian Tindakan Kelas (PTK), PTK dapat dikatakan penelitian eksperimen berulang atau eksperimen berkelanjutan, meskipun tidak selalu demikian. Apabila guru tidak puas dengan hasil yang dicapai setelah proses pembelajaran, dan ia ingin mengubah pembelajaran itu dengan model yang sifatnya baru sehingga mencobanya. Mencobanya tidak hanya satu kali saja, tetapi berulang-ulang (Suharsimi 2017). Penelitian ini bertempat di PAUD Permata Bunda pada Usia Anak 4-5 Tahun. Subjek penelitian ini diambil dari anak PAUD Permata Bunda pada anak usia 45 tahun yang berjumlah 15 orang anak.

Adapun tahap dalam penelitian ini adalah sebagai berikut :

\section{Perencanaan}

Terlebih dahulu penyusunan rencana merupakan tindakan pebelajaran dikelas yang tersusun.Pada tahap perencanaan siklus I di awali dengan refleksi dan analisis bersama antara peneliti dan guru terhadap pengenalan warna mengidentifikasikan masalah, menganalisa masalah dan mencari alternatif pemecahan masalah. Dari hasil tersebut di atas peneliti melakukan hal-hal sebagai berikut:

a. Menyusun rencana pelaksanaan pembelajaran harian dan rencana pelaksanaan pembelajaran mingguan siklus I. Hal ini difokuskan pada perencanaan langkahlangkah yang diambil dalam perbaikan atau skenario tindakan dan diharapkan dapat meningkatkan pengenalan warna pada anak dalam proses pembelajaran.

b. Menentukan tema pembelajaran

c. Menyiapkan bahan ajar yang akan digunakan pada proses pembelajaran

d. Menyiapkan lembar observasi dan melakukan dokumentasi

\section{Pelaksanaan}

Tindakan yang hendaknya dituntun oleh rencana yang telah dibuat, tetapi perlu diingat bahwa tindakan ini tidak secara mutlak dikendalikan oleh rencana, mengingat dinamik proses pembelajaran yang menuntut penyesuaian. Ada tahap pelaksanaan siklus I peneliti di bantu oleh guru (kolaborator) melaksanakan skenario pembelajaran seperti yang telah direncanakan di dalam RPPH yaitu sebagai berikut:
a. Guru merencanakan kondisi belajar yang lebih baik
b. Setelah selasai guru menyampaikan intruksi atau cara membuatnya
c. Guru meminta anak untuk mengerjakan tugas yang telah disediakan
d. Guru menyiapkan alat dan bahan yang akan digunakan

\section{Pengamatan}

Selama pelaksanaan tindakan pengenalan warna terhadap anak diadakan observasi. Observasi dilakukan bertujuan untuk mnegamati aktivitas-aktivitas anak selama proses pembelajaran. Hasil observasi dicatat pada lembar observasi yang telah disiapkan sebelumnya. Evaluasi hasil belajar ini dilaksanakan pada tiap akhir siklus. Kegiatan yang dilakukan pada tahap ini adalah: 
a. Mencari kelemahan atau kekurangan dalam proses pembelajaran serta memantau aktivitas anak denggan menggunakan lembar observasi

b. Mengadakan beberapa perbaikan pada siklus berikutnya.

\section{Refleksi}

Refleksi adalah mengingat dan merenungkan kembali suatu tindakan persis seperti yang telah dicatat di observasi .Hasil yang didapatkan dalam proses observasi di kumpulkan serta di analisis. Dari hasil analisis tersebut, peneliti melakukan refleksi diri.Dari hasil tersebut guru merancang tindakan siklus yang kedua.

\section{Siklus I}

1. Perencanaan

a. Peneliti dan guru kelas berdiskusi membuat 4 RPPH (Rencana Pelaksanaan Pembelajaran Harian) yang 4 pertemuan tatap mukadengan tema yang sesuai dengan RPPM (rencana pelaksanaan pembelajaran mingguan) di semester ganjil.

b. Menyiapkan lembar observasi dan dokumentasi

c. Peneliti menyiapkan bahan dan alat yang digunakan

2. Tindakan

a. Peneliti beserta guru yang bekerja sama memotivasi anak mengikuti kegiatan yang akan dibahas.

b. Peneliti menjelaskan pembelajaran kegiatan finger painting

c. Peneliti sebagai fasilitator dan memotivasi seluruh anak untuk mengikuti seluru kegiata pada hari itu.

3. Pengamatan

Peneliti berkolaborasi dengan guru pendamping untuk mengamati kegiatan pembelajaran dengan menggunakan finger painting dengan menggunakan instrument penelitian dan mencatat semua hal yang terjadi selama tindakan berlangsung dan dari hasil pengamatan dilakukan akan dilihat tingkat keberhasilan yang diharapkan.

4. Refleksi

Peneliti melakukan refleksi setelah melakukan pengamatan. Peneliti dan guru pendamping melakukan diskusi, menganalisis atau menyimpulkan data melalui observasi dan mengevaluasi terhadap yang dilakukan di dalam kegiatan pembelajaran.

Apabila hasil belum sesuai yang diharapkan oleh penelit, maka akan dilakukan persiapan untuk melanjutkan pada siklus selanjutnya.

\section{Siklus II}

1. Perencanaan

a. Peneliti dan guru kelas berdiskusi membuat $4 \mathrm{RPPH}$ (rencana pelaksanaan pembelajaran harian) yang 4 pertemuan tatap mukadengan tema yang sesuai dengan RPPM (rencana pelaksanaan pembelajaran mingguan) di semester ganjil.

b. Menyiapkan lembar observasi dan dokumentasi

c. Peneliti menyiapkan bahan dan alat yang digunakan

2. Tindakan

Pada tahap pelaksanaan kegiatan yang akan dilakukan secara garis besar sama pada siklus 1 .

3. Pengamatan

Pada pengamatan ini bisa dikatakan sama pada siklus I. peneliti dan guru team berkolaborasi akan mengamati aktivitas dalam melakukan kegiatan pembelajaran dengan menggunakan finger painting, sehingga di lihat tingkat pencapaian perkembangan pada siklus II sebagai bahan perbaiakn pada siklus berikutnya.

4. Refleksi

5 | ZURIAH : Jurnal Pendidikan Anak Usia Dini, Vol. 1 No. 1, Mei 2020 
Dari hasil pengamatan peneliti besama gurupendamping menganalisis dan mengumpulkan data melalui instrument penelitian sehingga dapat diketahui tingkat keberhasilan yang diharapkan telah tercapai secara optimal.

\section{B. HASIL DAN PEMBAHASAN}

\section{Hasil}

\section{A. Siklus I}

Siklus I dilakukan sebanyak 4 kali, pertemuan pertama dilakukan pada hari senin, tanggal 21 Oktober 2019, pertemuan kedua dilaksanakan senin, tanggal 28 oktober 2019, pertemuan ketiga dilakukan pada hari senin, tanggal 04 november 2019, dan peremuan keempat dilakukan pada hari senin, pada tanggal 11 november 2019. Sebelum melakukan penelitian penelitian guru mempersiapkan Satuan Kegiatan Harian (SKH) secara keseluruhan. Tindakan siklus I dapat dilaksanakan sesuai dengan rencana yang telah dibuat sebelumnya dengan langkah- langkah sebagai berikut.

1. Perencanaan Tindakan

Sebelum melakukan penelitian dimulai dengan dengan melakukan analisis untuk menentukan indikator yang akan dikembangkan pada anak. Aspek yang dinilai adalah warna primer, warna sekunder, warna tersier. Perencanaan yang dilakukan adalah dengan membuat persiapan mengajar seperti menyiapkan rencana kegiatan harian (RKH), dan mempersiapkan bahan-bahan yang akan digunakan didalam pelaksanaan pembelajaran yaitu pewarna untuk melakukan kegiatan finger painting.

2. Pelaksanaan Tindakan

Guru melaksanakan finger painting dengan rencana kegiatan harian yang telah disusun.

3. Observasi

Pada siklus I pertemuan pertama, selama kegiatan belajar berlangsung maka peneliti mendapatkan adanya peningkatan pengenalan warna pada anak akan tetapi belum maksimal. Berdasarkan data- data yang diperoleh dari siklus I pertemuan ke1 baik hasil pengamatan, penilaian proses maupun hasil penilaian pengenalan warna melalui finger painting di PAUD Permata Bunda Muaro Jambi anak masih cukup dalam pengenalan warna. Hasil sementara pada siklus I pertemuan ke-1 peningkatan pengenalan warna melalui finger painting di PAUD Permata Bunda Muaro Jambi anak masih belum cukup optimal persentase 25,33\%.

Pertemuan kedua dilaksanakan senin, tanggal 28 oktober 2019 Sebelum melakukan penelitian guru mempersiapkan satuan kegiatan harian (SKH) secara keseluruhan. Berdasarkan data- data yang diperoleh dari siklus I pertemuan ke-2 baik hasil pengamatan, penilaian proses maupun hasil penilaian pengenalan warna melalui finger painting di PAUD Permata Bunda Muaro Jambi anak masih cukup dalam pengenalan warna Hasil sementara pada siklus I pertemuan ke-2 peningkatan pengenalan warna melalui finger painting di PAUD Permata Bunda Muaro Jambi anak masih belum cukup optimal persentase $35,55 \%$

Hasil observasi pertemuan ketiga dilakukan pada hari senin, tanggal 04 november 2019. Berdasarkan data- data yang diperoleh dari siklus I pertemuan ke-3 baik hasil pengamatan, penilaian proses maupun hasil penilaian pengenalan warna melalui finger painting di PAUD Permata Bunda Muaro Jambi anak masih cukup dalam pengenalan warna. Hasil sementara pada siklus I pertemuan ke-3 peningkatan pengenalan warna melalui finger painting di PAUD Permata Bunda Muaro Jambi anak belum cukup optimal persentase 46,00\% 
Pertemuan keempat dilakukan pada hari senin, pada tanggal 11 november 2019. Sebelum melakukan penelitian penelitian guru mempersiapkan satuan kegiatan harian (SKH) secara keseluruhan. Data yang diperoleh dari siklus I pertemuan ke-4 baik hasil pengamatan, penilaian proses maupun hasil penilaian pengenalan warna melalui finger painting di PAUD Permata Bunda Muaro Jambi anak masih belum cukup dalam pengenalan warna.

Untuk melakukan penelitian pada siklus II. Peneliti menyimpulkan hasil perbandingan pratindakan dengan siklus I dalam bentuk grafik sebagai berikut:

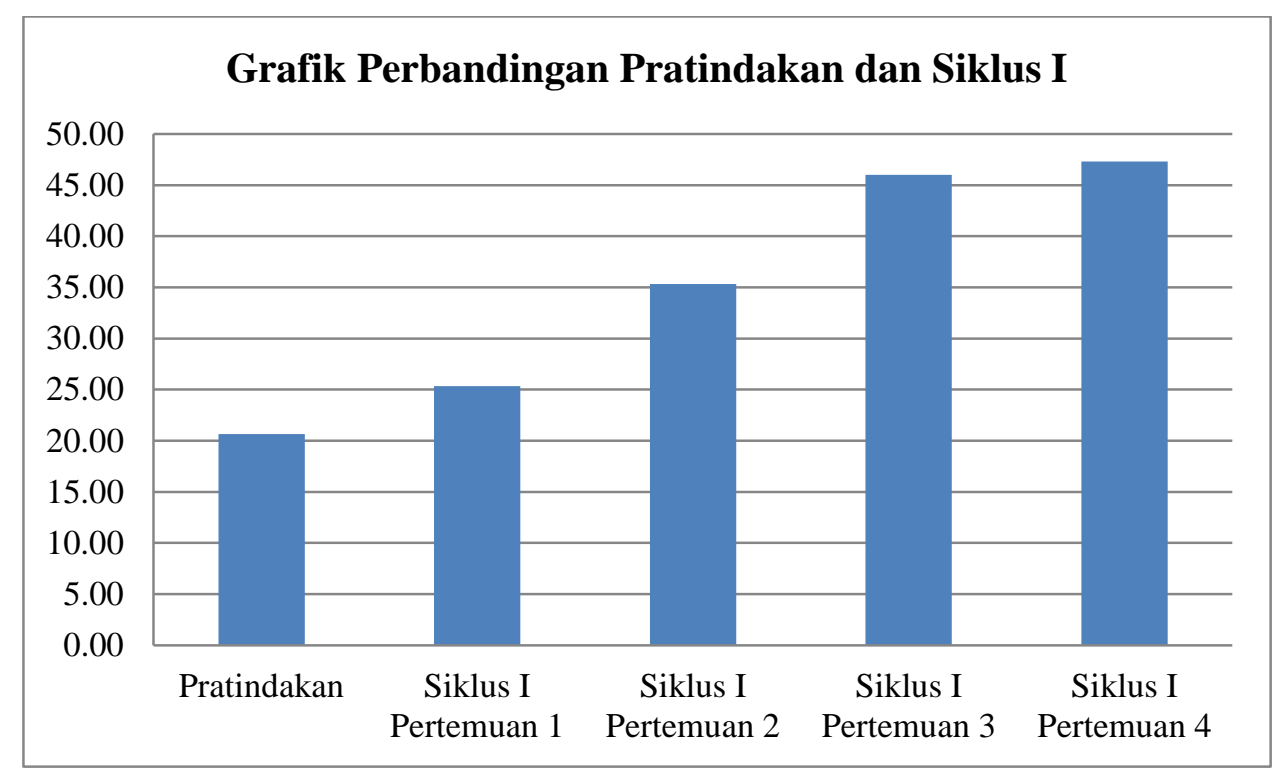

Gambar 4.2. Grafik Perbandingan Pratindakan dan Siklus I

Berdasarkan grafik perbandingan di atas, bahwa sebelum melakukan penelitian pengenalan warna di PAUD Permata Bunda masih banyak anak yang kurang dalam mengenal warna 20,69\%, sedangkan ketuntasan $90 \%$ pada siklus I Pengenalan warna apada anak baru sedikit meningkat dilihat dari persentase pratindakan 20,69\% menjadi 47,33\% pada siklus I pertemuan ke 4, pengenalan warna anak sudah meningkat tapi masih perlu tindakan selanjutnya untuk mencapai ketuntasan. Oleh karena itu peneliti merencanakan kembali langkah-langkah yang akan dilakukan lagi di siklus II.

\section{SIKLUS II}

Siklus II dilakukan sebanyak 4 kali , pertemuan pertama dilakukan pada hari senin, tanggal 18 november 2019. Sebelum melakukan penelitian penelitian guru mempersiapkan satuan kegiatan harian (SKH) secara keseluruhan. Berdasarkan data yang dari hasil sementara pada siklus I pertemuan ke-4 peningkatan penegenalan warna melalui finger painting di PAUD Permata Bunda kelihatan cukup dengan persentase 47,33\% dan masih butuh bimbingan dari peneliti. Sehingga peneliti melanjutkan penelitiannya ke pertemuan selanjutnya.

Pertemuan kedua siklus II dilakukan pada hari senin, tanggal 25 november 2019. Sebelum melakukan penelitian penelitian guru mempersiapkan satuan kegiatan harian (SKH ) secara keseluruhan. Berdasarkan data- data yang diperoleh dari siklus II pertemuan ke-2 peneliti mengamati kegiatan finger painting untuk meningkatkan pengenalan warna pada anak $68,00 \%$ sudah baik. Anak sudah bisa mengenal warna dengan baik melalui hal yang dilakukannya.

Pertemuan ketiga siklus II dilakukan pada hari senin, tanggal 2 desember 2019. Sebelum melakukan penelitian penelitian guru mempersiapkan satuan kegiatan harian (SKH 
) secara keseluruhan. Berdasarkan data- data yang diperoleh dari siklus II pertemuan ke-2 peneliti mengamati kegiatan finger painting untuk meningkatkan pengenalan warna pada anak $80,67 \%$ sudah sangat baik. Anak sudah bisa mengenal warna dengan sangat baik melalui hal yang dilakukannya.

Pertemuan keempat siklus II dilakukan pada hari senin, tanggal 9 Desember 2019. Sebelum melakukan penelitian guru mempersiapkan satuan kegiatan harian (SKH) secara keseluruhan. Berdasarkan data-data yang diperoleh dari siklus II pertemuan ke-4 peneliti mengamati kegiatan finger painting untuk peningkatan pengenalan warna anak sebesar $90,00 \%$ sudah berkembang sangat baik. Anak sudah mampu menyebutkan warna sesuai dengan yang dibuatnya melalui finger painting dengan sangat baik.

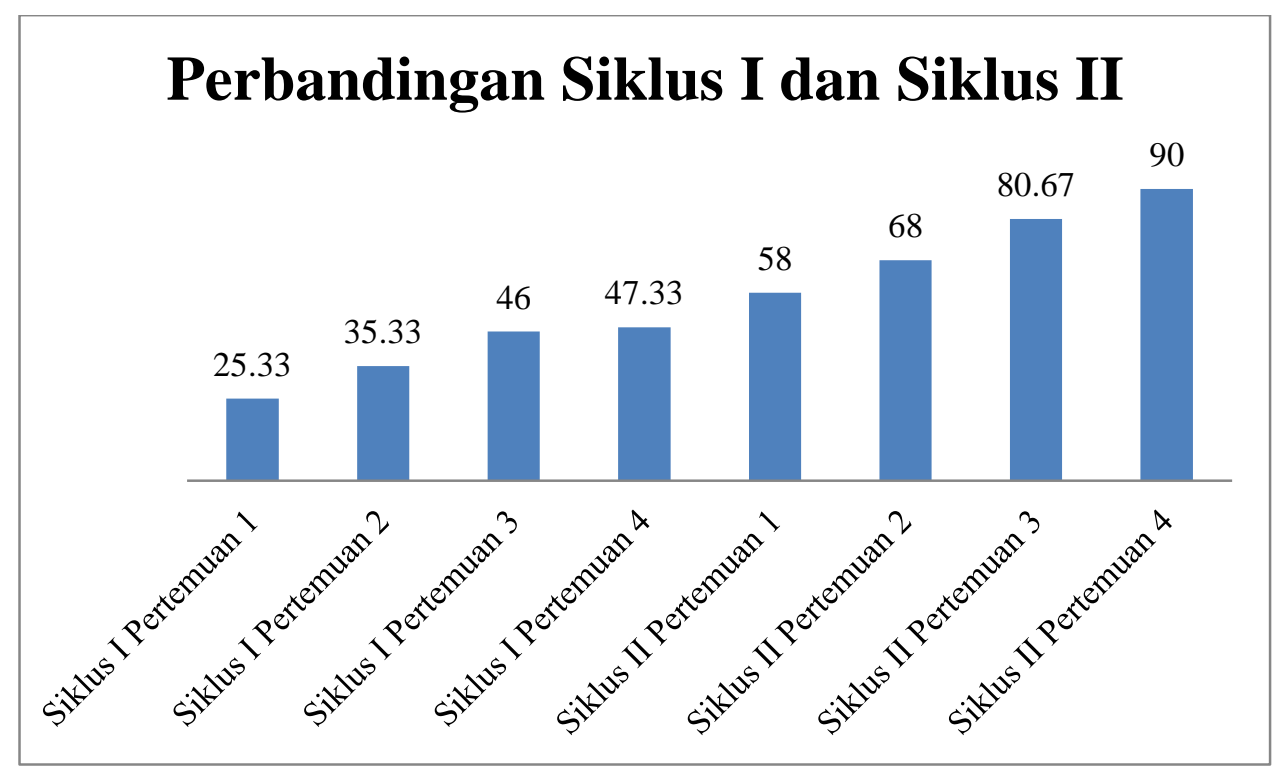

Gambar 4.3. Grafik Perbandingan Siklus I dan Siklus II

Berdasarkan grafik prbandingan diatas, bahwa sebelum melakukan penelitian pengenalan warna melalui finger painting di PAUD Permata Bunda 47,33\%. Sedangkan ketutasan 90\%. Pada siklus I pertemuan ke-1 dengan hasil 25,33\% Menjadi 90\% pada siklus II pertemuan ke-4, pengenalan warna anak sudah berkembang sangat baik sesuai denga tingkat pencapaian dan mencapai ketuntasan.

\section{Pembahasan}

Pembahasan hasil penelitian ini membahas tentang meningkatkan pengenalan warna melalui finge painting pada anak usia 4-5 tahun di PAUD Permata Bunda, yaitu dalam proses pembelajaran yang melalui finge painting untuk menyampaikan materi kepada anak sesuai dengan kebutuhan. Oleh karena itu dengan kegiatan finger painting yang menyenangkan bagi anak, sehingga proses pembelajaran menjadi lebih menarik, anak-anak juga terlihat antusias untuk mengikuti pembelajaran.

Pengenalan warna adalah proses perbuatan mengenali cahaya yang dipantulkan oleh benda yang dikenainya. Pada penelitian ini yang dimaksud dengan pengenalan warna yaitu kecakapan anak untuk menyebutkan macam-macam warna dan menyampaikan hasil percobaan tentang percampuran warna.

Berdasarkan hasil pelaksanaan pembelajaran dan hasil refleksi yang dilakukan selama dua siklus menunjukka adanya dampak positif dari kegiatan pratindakan, siklus I dan siklus II. Proses kegiatan melalui finger painting ini lebih menarik dan menyenangkan. Jadi pada siklus II pengenalan warna meningkat sebesar 90\% sehingga berada pada kriteria sangat baik. Oleh karena itu peneliti menganggap hasildari siklus II ini, telah sesuai dengan 
hipotesis yang diajukan. Dan dapat disimpulkan bahwa penelitian tindakan kelas dngan kegiatan finger painting dapat meningkatkan pengenalan warna pada anak.

Hasil analisis perbandingan anatara pratindakan, siklus I dan siklus II dapat kita lihat grafik di bawah ini.

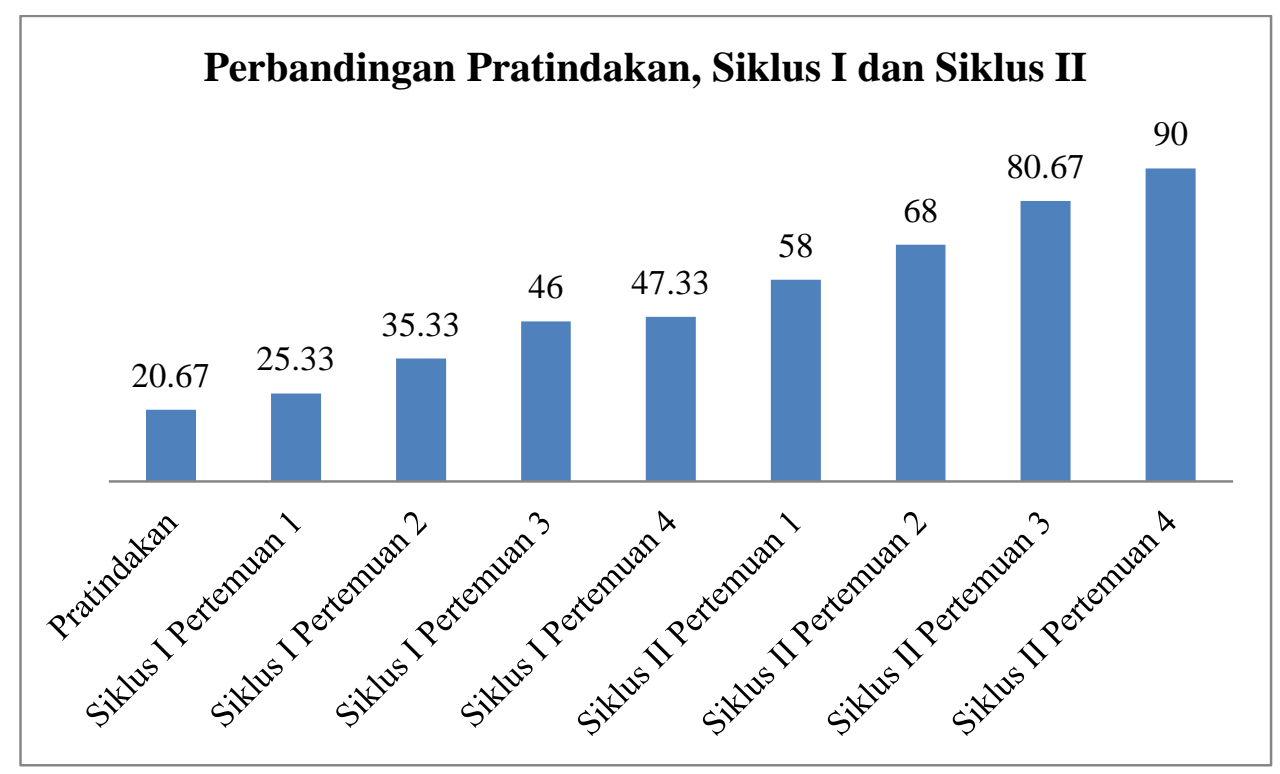

\section{Gambar 4.4. Grafik Perbandingan Pratindakan Siklus I dan Siklus II}

Berdasarkan grafik hasil penelitian diatas dapat disimpulkan bahwa dari pratindakan sampai ke akhir siklus II pengenalan warna pada anak usia 4-5 tahun di PAUD Permata Bunda memiliki peningkatan setiap siklusnya. Dari pratindakan 20,67\%, siklus I pertemuan ke-4 : 47,33\%, dan siklus II pertemuan ke-4 : 90\% maka meningktakan pengenalan warna melalui finger painting di PAUD Permata Bunda Muaro Jambi berkembang sangat baik dan mencapai ketuntasan.

Finger Painting menjadi salah satu strategi yang bisa digunakan guru dalam meningkatkan kemampuan anak dalam mengenali warna. Melalui finger painting anak diajak belajar sambil bermain. Selain anak bisa mengenali lebih banyak warna, anak juga merasa riang dan tertantang untuk mengetahui warna-warna yang belum diketahui sebelumnya. Gurupun merasa lebih mudah mengajarkan jenis-jenis warna kepada anak didiknya.

Sejalan dengan hal tersebut finger painting dapat mengembangkan semua aspek perkembangan anak, menemukan berbagai pengalaman yang didapat dari berbagai aktivitasaktivitasnya, anak akan secara aktif dan terlibat langsung berinteraksi dengan teman sebaya dan lingkungannya. dapat berimajinasi melalui ide-idenya, lebih bebas dalam bereksplorasi dalam, secara langsung dapat meningkatkan kemandirian anak, memiliki kemampuannya menciptakan warna dari adonan yang diciptakan anak melalui pancaindranya mengamati dan merasakan aktivitas mencampur bubur warna dari jari tangannya, dan berkata aku bisa, dan macam-macam warna serta aktivitas ini membantu anak dalam berkonsentrasi pada saat melukis sangat baik bagi anak dan merupakan bahan yang mudah di dapat dan harganya relatif murah, selain itu kemampuan anak dalam bahasa (Fadilla 2017).

\section{KESIMPULAN DAN SARAN}

Berdasarkan hasil penelitian dapat diambil kesimpulan bahwa:

1. Sebelum diberi tindakan pengenalan warna melalui finger painting anak belum berkembang secara optimal terlihat pada saat peneliti melakukan observasi anakanak belum mampu menyebutkan warna yang benar. 
2. Meningkatkan pengenalan warna melalui finger painting di PAUD permata bunda muaro jambi persentase anak pada pratindakan $20,67 \%$, siklus I $47,33 \%$ dan siklus II $90 \%$.

Dari kesimpulan diatas, penulis dapat memberikan saran untuk perubahan demi kesempurnaan penelitian tindakan kelas pada masa mendatang adalah:

1. Bagi Anak

Diharapkan dengan finger painting dapat meningkatkan pengenalan warna dan melalui kegiatan ini diharapkan bagi anak supaya dapat menemukan dengan sendirinya warna-warna baru.

2. Bagi Guru

Diharapkan dapat menggunakan sebagai acuan dalam proses pembelajaran yang diterapkan oleh guru dalam kelas dan menjadi pembelajaran kreatif untuk meningkatkan pengenalan warna pada anak.

3. Bagi Sekolah

Diharapkan dapat digunakan untuk sebagai upaya dalam meningkatkan pendidikan yang menggunakan teknik yang tepat dan sesuai sehingga tercapainya perkembangan yang optimal.

\section{DAFTAR PUSTAKA}

Anggraini, Septi, Thoha B. S. Jaya, dan Ari Sofia. 2018. "Pengaruh Aktivitas Permainan Finger Painting terhadap Pengenalan Warna Anak Usia 5-6 Tahun.” Jurnal Pendidikan Anak 4 (2). http://jurnal.fkip.unila.ac.id/index.php/PAUD/article/view/17150.

Fadilla, Nur. 2017. "MENINGKATKAN KEMAMPUAN MENGENAL WARNA SEKUNDER MELALUI KEGIATAN MELUKIS DENGAN JARI (FINGER PAINTING) KELOMPOK B DI PPT ASSALAM SURABAYA." PAUD Teratai 6 (3). https://jurnalmahasiswa.unesa.ac.id/index.php/paudteratai/article/view/19479.

Karuniawati, Anis. 2017. "PENGARUH FINGER PAINTING TERHADAP KEMAMPUAN MENGENAL KONSEP WARNA PADA ANAK KELOMPOK A." PAUD Teratai 6 (3). https://jurnalmahasiswa.unesa.ac.id/index.php/paud-teratai/article/view/19890.

Meldina, Tika. 2019. "IMPLEMENTASI MODEL LEARNING START WITH A QUESTION STRATEGI MENINGKATKAN KETERAMPILAN BERTANYA SISWA SEKOLAH DASAR." TERAMPIL: Jurnal Pendidikan dan Pembelajaran Dasar 6 (2): 211-19. https://doi.org/10.24042/terampil.v6i2.5138.

Sofyan, Hendra. 2015. Perkembangan Anak Usia Dini dan Cara Praktis Peningkatannya. Jakarta: CV. Infomedika.

Suharsimi, Arikunto. 2017. Prosedur Penelitian. Jakarta: Bumi Aksara.

Sujiono, Yuliani Nurani. 2013. Konsep Dasar Pendidikan Anak Usia Dini. Jakarta: PT Indeks. Suyadi, dan Ulfah Maulidya. 2013. Konsep Dasar PAUD. Bandung: PT Remaja Rosdakarya. 